Espacio y Desarrollo No 35, 2020, pp. 39-69 (e-ISSN 2311-5734)

https://doi.org/10.18800/espacioydesarrollo.202001.002

\title{
De LA ACUMULACIÓN PRIMITIVA A LA ACUMULACIÓN POR DESPOSESIÓN: SUPEREXPLOTACIÓN LABORAL EN LA COSECHA DE YERBA MATE DEL NORDESTE ARGENTINO (1870-2018)
}

\author{
Sebastián Gómez Lende \\ https://orcid.org/0000-0002-3510-9650 \\ Instituto de Geografía, Historia y Ciencias Sociales, CONICET \\ gomezlen@fch.unicen.edu.ar
}

Fecha de recepción: 03/03/2020 Fecha de aceptación: 18/11/2020

\section{Resumen}

Lejos de limitarse a una etapa "originaria" o "primitiva", la acumulación por desposesión y sus distintas formas de superexplotación laboral constituyen una fuerza importante y permanente de la geografía histórica del capital. A la luz de esta premisa, este artículo analiza el derrotero de las prácticas de semiesclavitud, violencia, fraude, súper explotación laboral y recorte y avasallamiento de derechos sufridas por los cosecheros de yerba mate de las provincias de Misiones y Corrientes (Argentina) desde la segunda mitad del siglo XIX hasta la actualidad. Se consideraron cinco categorías de análisis: regímenes de reclutamiento, precarización y disciplina laboral ligados a los procesos de violación o pérdida de derechos; intensidad y duración de la jornada de trabajo; salarios y fraudes; trabajo infantil y desposesión del derecho a la salud; y connivencia estatal. Los resultados muestran que las formas pretéritas de explotación laboral de la actividad no configuraron solo mecanismos iniciales de la acumulación capitalista regional, sino que se reorganizaron para convertirse en rasgos estructurales de un modelo secular donde las relaciones entre capital y trabajo se basan primordialmente en el despojo.

Palabras-clave: capitalismo, acumulación por desposesión, explotación laboral, yerba mate, Argentina.

From primitive accumulation to accumulation by despossession: labour superexploitation in the yerba mate harvest of the Argentinean northwest (1870-2018)

\section{Abstract}

Instead staying limited to an 'originary' or 'primitive' stage, accumulation by dispossession and its diverse ways of labour super exploitation constitute a permanent and important force of the historic geography of capital. Considering such premise, this paper analyses the course 
of the practices of semi-slavery, violence, fraud, labour superexploitation and cutting and seizure of rights suffered by the yerba mate harvesters of the provinces of Misiones and Corrientes (Argentina) from the middle of the XIX Century to nowadays. In order to do this, five categories of analysis were considered: the regimes of recruitment, precarization and discipline of the workforce, which are linked with the loss and violation of workers' rights; the intensity and duration of the labour workday; wages and frauds; child labour and the dispossession of the right to health; and the state complicity. The results show that the old ways of labour exploitation do not only were initial mechanisms of accumulation of capital at regional scale, but were reorganized to become structural features of a secular pattern where the relations between capital and workforce have been mostly based in looting.

Keywords: capitalism, accumulation by dispossession, labour exploitation, yerba mate, Argentina.

\section{INTRODUCCIÓN}

A lo largo de su existencia, el capitalismo siempre se ha caracterizado por el desarrollo de una acumulación que, basada en la depredación, el fraude y la violencia, ha operado de modo paralelo - y a veces subterráneo - a la reproducción ampliada (Harvey, 2004; 2014). Lo que Marx (1968) dio en llamar «acumulación primitiva» es en realidad una fuerza importante y permanente de la geografía histórica del capital, una fuerza que reaparece una y otra vez para configurar un proceso secular de «acumulación por desposesión» (Harvey, 2004) que experimenta cíclicamente fases de ralentización y aceleración. América Latina, en general, y la Argentina, en particular, se hallan actualmente inmersas en un período de recrudecimiento de las dinámicas expropiatorias del capital donde se solapan varios mecanismos reconocidos por la literatura marxista y neomarxista: privatización y mercantilización de la tierra, expulsión y proletarización de campesinos y aborígenes, eliminación de formas de producción y consumo precapitalistas y apropiación colonial, neocolonial e imperial de recursos naturales; así como deuda externa y expoliación financiera, eliminación de regímenes de propiedad colectiva, comunal y/o estatal, redistribuciones estatales, mercantilización de la naturaleza, despojo ecológico, y desarrollo de derechos de propiedad intelectual sobre material genético (Harvey, 2004, 2007, 2014). Muchos de esos fenómenos no son nuevos, sino que encarnan formas perfeccionadas de mecanismos más antiguos cuya génesis se remonta al siglo XIX, cuando nuestro país ingresó en la división internacional del trabajo.

Guardando ciertas reminiscencias con tiempos pretéritos, la problemática de las distintas formas de esclavitud y súper explotación laboral forma parte de las cuestiones medulares sobre las que se asientan las dinámicas expropiatorias del capital. De hecho, Marx (1968) confirió un papel destacado a la fuerza de trabajo y las relaciones laborales dentro de los mecanismos que enunció y describió para caracterizar a la acumulación 'originaria'. El pensador alemán se refirió a la súper explotación laboral, la reducción 
salarial por debajo del nivel de subsistencia, la prohibición explícita de la sindicalización de los obreros, el robo de niños de los asilos parroquiales para someterlos a las inhumanas condiciones laborales de los distritos fabriles ingleses, la conversión del continente africano en un cazadero de esclavos negros, el tráfico humano con destino a América y la esclavización de los pueblos originarios de este último continente (Marx, 1968). De hecho, el resurgimiento de la esclavitud mediante distintos mecanismos — contratos, engaños, raptos, cacerías humanas - fue uno de los más extraordinarios motores de la acumulación del capital comercial europeo, así como uno de los cimientos sobre los cuales se edificó el capitalismo industrial (Bagú, 1969).

Siglos después, se hallan por doquier las señales de que el capitalismo no pocas veces se aparta de la explotación «normal» del proletariado —entendida como la producción de mercancías por un valor mayor al del precio de mercado de su fuerza de trabajopara incursionar en formas mucho más descarnadas, violentas y con frecuencia extralegales de apropiación de la plusvalía. Todavía persisten, por ejemplo, los regímenes de súper explotación tal como los define Marini (1991), es decir, basados en la extensión de la jornada laboral, la reducción de las remuneraciones por debajo del umbral mínimo de subsistencia o costo de reproducción de la fuerza de trabajo y el aumento de la plusvalía debido al incremento de la intensidad del trabajo. Por otra parte, el endeudamiento en el lugar de trabajo (como el derivado del peonaje por deudas) sigue siendo una de las formas más insidiosas de apropiación del trabajo o del producto del trabajo ajeno por quienes detentan poder social, político o dinerario (Harvey, 2014). Ni siquiera puede decirse que la esclavitud laboral, sexual e infantil haya desaparecido.

Durante los últimos cuarenta años, la hegemonía neoliberal ha acarreado además un acusado proceso de «destrucción creativa» de marcos y poderes institucionales de protección social, lo que ha conllevado una profundización de la mercantilización de la fuerza laboral mediante diversos mecanismos. El redoblado asalto del capital contra la fuerza de trabajo ha domeñado o desmantelado el poder de los sindicatos y otras instituciones obreras, lo que ha devenido en la supresión o menoscabo de derechos sociales y laborales tales como pensiones de jubilación, sanidad y otros elementos que integran el salario social duramente adquiridos tras décadas de encarnizada lucha de clases (Harvey, 2004, 2014).

Bajo el eufemismo de la «flexibilización laboral», la "carrera hacia la máxima reducción de los límites normativos» (Harvey, 2007) se ha acelerado para permitir al capital usufructuar reservas más baratas y dóciles de fuerza de trabajo y convertir al obrero «desechable» en un prototipo de las nuevas relaciones laborales del capitalismo contemporáneo. Esta lógica alcanza su máxima expresión en las prácticas denigrantes y las despóticas condiciones laborales que rigen en los talleres de trabajo esclavo y las redes de sub-contratación que, distribuidas por todo el planeta, tienen su epicentro en el sur del continente africano, gran parte de Asia (China, Corea del Sur, Indonesia, Malasia, Tailandia, etc.) y algunos países de América Latina (México, Honduras, etc.). 
Allí son habituales los salarios pagados con meses de retraso —o salarios que directamente no son abonados-, las jornadas laborales de quince horas diarias, la alimentación insuficiente, y los accidentes y riesgos para la salud, todo ello en un marco carente de toda regulación pública (Harvey, 2007). En síntesis, el despojo directo del valor producido por el trabajo social en el lugar de producción continúa siendo un eslabón primordial de la inmensa y flexible cadena de desposesión que nutre y sostiene la apropiación y acumulación de la riqueza común en manos del capital (Harvey, 2014).

En el nordeste argentino, y en concreto, en las provincias de Misiones y Corrientes, la producción de yerba mate nunca ha sido ajena a estas dinámicas laborales. Aunque generalmente los estudios académicos acerca de este sector se enfocan en la situación de los pequeños productores agrícolas, el eslabón más débil, vulnerable y castigado son los trabajadores rurales, quienes, pese a recolectar la hoja verde bajo condiciones de extrema precariedad laboral, históricamente siempre han sido «invisibles» en términos políticos y sociales (Rau, 2012). Un siglo y medio atrás, cuando la actividad se desarrollaba bajo criterios extractivos, esta función era desempeñada por los «mensúes» — también denominados «macheteros» $\mathbf{o}$ «mineros»—, fuerza de trabajo semi-esclava que recogía la materia prima de los yerbales silvestres. Con el paso del tiempo y el avance de la agricultura, los miembros de este universo de explotados pasaron a ser llamados «tareferos» —vocablo que proviene del portugués «tarefa», que significa «tarea»—, convirtiéndose en asalariados estacionales o semi ocupados. Aún hoy día, y a diferencia de otros circuitos agroindustriales del norte argentino, la zafra yerbatera continúa siendo casi por completo manual. Si bien se han implementado marginalmente ciertas formas de mecanización y semi-mecanización, no existe máquina ni herramienta que sustituya a la mano humana en esa delicada tarea, pues las hojas no pueden quebrarse ni aplastarse sin dar lugar al prematuro inicio de la oxidación y degradación de sus propiedades (Corbey, Koffman, Orso, Ribone, Rodríguez \& Uría, 2013; Pereyra, 2013).

Existen algunos trabajos académicos que desde las ciencias sociales se han dedicado enteramente a abordar la problemática de los mensúes y los tareferos. Sobresalen, entre otros, el aporte conjunto de análisis histórico y cinematográfico desarrollado por Alvira (2009) acerca del régimen laboral de los mensúes, y el relevamiento de las condiciones de vida y trabajo de los cosecheros de Flood (1972). También deben mencionarse los estudios sobre la precarización del mercado de trabajo agrario y los mecanismos de protesta social de los tareferos (Rau, 2012), la incorporación de las cuestiones de identidad (Roa, 2013) y género (Haugg, 2016), el trabajo infantil en la cosecha (Pereyra, 2013; Re, 2015) y los impactos de las políticas públicas y la intervención estatal desplegados sobre ese mercado de trabajo rural (Traglia, 2014). Más recientemente, una compilación realizada por Gortari, Roa y Re (2017) efectuó un exhaustivo abordaje de la larga historia de vulnerabilidad social y explotación laboral que ha atravesado la recolección de yerba mate de sus inicios hasta la actualidad. 
Sin perjuicio del valor, calidad y riqueza empírica de todos los trabajos citados, y pese a que algunos de ellos dan cuenta de la «reaparición» entre los cosecheros yerbateros contemporáneos de condiciones muy semejantes a las de los mensúes de antaño, ninguno ha realizado un abordaje integral que discuta con profundidad teórica la problemática a la luz del concepto de acumulación por desposesión. Rau (2012) se limita a señalar el papel de la violencia en la proletarización de los mensúes y el tránsito de las relaciones sociales pre-capitalistas a las capitalistas en la estructuración del mercado de trabajo rural misionero, en tanto que un artículo incluido en la compilación más arriba mencionada efectúa referencias tangenciales a los nexos entre la acumulación originaria y la explotación de los mensúes, sin ahondar sobre el particular (Gortari, 2017b). Por otra parte, en el ámbito académico argentino existe cierta tendencia a considerar que las prácticas patronales sufridas por los trabajadores rurales de las economías regionales del interior del país no son rasgos estructurales o medulares del capitalismo, sino que reflejarían la pervivencia de características semi-feudales.

Buscando cubrir esa área de vacancia, este artículo realiza un análisis del derrotero histórico que, desde la segunda mitad del siglo XIX hasta la actualidad, siguió la evolución de la figura del mensú a la del tarefero en la cosecha de yerba mate en el nordeste argentino. La hipótesis de trabajo sostiene que las formas pretéritas de explotación laboral de la actividad no constituyeron apenas mecanismos de acumulación 'primitiva' propios del singular proceso de formación del capitalismo en la región; antes bien, también fundaron los cimientos para el desarrollo constante y sistemático de un proceso de acumulación de desposesión que, con arreglo a las circunstancias de cada período histórico, se ha extendido hasta nuestros días y reúne todas las formas de despojo reconocidas por la teoría en cuanto a las relaciones entre capital y trabajo (semiesclavitud, violencia, fraude, súper explotación laboral, recorte legal y avasallamiento ilegal de derechos, trabajo infantil, afectación de la salud, etc.).

Luego de ensayar una breve caracterización del universo de estudio, el artículo desarrolla transversalmente cada una de las categorías de análisis reconstruidas para tal fin: los regímenes de reclutamiento, precarización y disciplina laboral y la violación o pérdida de derechos; la intensidad y duración de la jornada de trabajo; los salarios y los fraudes; el trabajo infantil y la desposesión del derecho a la salud; y la connivencia del Estado. Finalmente, se presentan las conclusiones del trabajo.

\section{Caracterización histórico-geOgráfica del SECTOR Yerbatero y DEL ÁREA DE ESTUDIO}

La yerba mate (Ilex paraguariensis) es una planta arbórea nativa de la Selva Paranaense y típica del sotobosque del sur atlántico brasileño, el oeste paraguayo y el nordeste argentino. En este último caso, abarca buena parte de la provincia de Misiones y el nordeste de la provincia de Corrientes (departamentos de Ituzaingó y Santo Tomé) (Ver Figura 1). 
Figura 1. Departamentos productores de yerba mate en las provincias de Misiones y Corrientes (República Argentina)

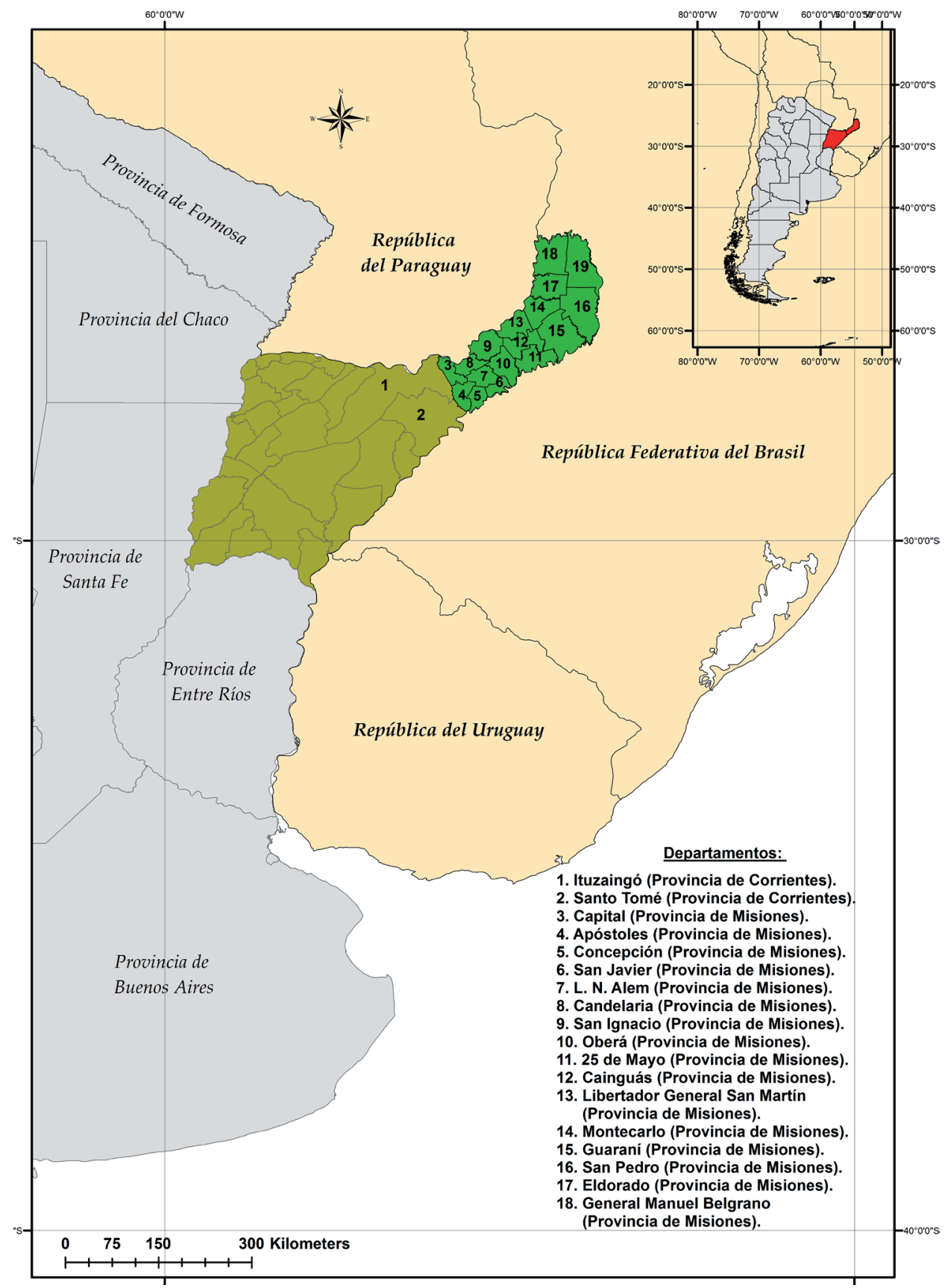


Originariamente, su explotación no fue agrícola, sino extractiva. A excepción del período jesuita (1645-1767), desde mediados del siglo XVI hasta comienzos del siglo XX la producción consistió en la explotación de yerbales silvestres con criterio «minero» - es decir, extractivo, sin atender a la renovación del recurso-. Esta forma de uso del territorio alcanzó su máximo esplendor entre 1875 y 1930, lo que supuso la conformación de la etapa del frente extractivo (Rau, 2012), surgida luego de que la Guerra de la Triple Alianza (1865-1870) despojara al Paraguay del territorio misionero y lo pusiera bajo control argentino — bajo la jurisdicción de Corrientes primero y bajo la órbita del Estado nacional después-.

Si bien los primeros cultivos se iniciaron en 1903, el verdadero punto de inflexión se produjo a finales de la década de 1920, cuando las políticas de fomento de la agricultura y colonización agraria determinaron que, ante la copiosa afluencia de inmigrantes europeos, la yerba mate se convirtiera en una suerte de "cultivo poblador» del territorio ${ }^{1}$. Fue entonces cuando el circuito productivo asumió la estructura que posee en la actualidad.

Con una vida útil de aproximadamente treinta años, la yerba mate es un cultivo de ciclo perenne que involucra a explotaciones de reducida extensión (promedio de veinticinco hectáreas), aunque en algunos casos pueden alcanzar las cien o incluso las cuatrocientas hectáreas. Cosechada entre abril y octubre de cada año — aunque también existe una pequeña zafra estival durante el mes de diciembre-, la hoja verde es destinada a los secaderos de la región para su deshidratación mediante el "zapecado» ${ }^{2}$ y el secado propiamente dicho, tras el cual se prosigue con una molienda gruesa (canchado) y un período variable de estacionamiento. La siguiente y última etapa agroindustrial se desarrolla en los molinos y las plantas fraccionadoras instaladas dentro y fuera de la región productora - provincias de Misiones y Corrientes en el primer caso y de Santa Fe y Buenos Aires en el segundo-, donde se llevan a cabo las operaciones de clasificación, molienda fina, mezcla y envasado.

\footnotetext{
1 El concepto de «cultivo poblador del territorio» se refiere a aquellas producciones agrícolas regionales que entre la segunda mitad del siglo XIX y las primeras décadas del siglo XX fueron promocionados por el Estado argentino para alentar, consolidar y expandir la presencia en determinadas regiones y áreas de frontera de población estable que por lo general estuvo constituida por contingentes migratorios europeos. Además de la yerba mate en Misiones, otros ejemplos de esta lógica fueron el algodón en Chaco, Formosa y Santa Fe, la vid en Mendoza, el tabaco en Misiones y los frutales en el norte patagónico. En ese contexto, la funcionalidad de tales cultivos a la hora de asegurar el poblamiento del territorio radicaba en que se trataba de producciones agrícolas que, al estar exclusivamente destinadas al mercado, permitían a las familias de colonos obtener ingresos monetarios con los cuales complementar sus economías de autosubsistencia.

2 El «zapecado» consiste en un primer golpe de calor (temperatura aproximada de $120{ }^{\circ} \mathrm{C}$ ) al que es sometida la hoja verde de yerba mate para detener los procesos enzimáticos y romper las vesículas de agua, evitando así la putrefacción de la materia prima.
} 
A raíz de la competencia de las importaciones de yerba brasileña, la agricultura yerbatera del nordeste argentino entró en crisis al poco tiempo de haberse iniciado. Sus agudos picos de sobre-oferta determinaron que en 1935 y 1936, a comienzos de la industrialización sustitutiva de importaciones (1930-1975), el gobierno nacional creara la Comisión Reguladora de la Yerba Mate (CRYM) y el Mercado Concentrador de la Yerba Mate (MCYM), dos organismos formados tanto por cuadros técnicos, financieros y políticos del Estado como por representantes del sector privado que establecieron cupos de siembra y cosecha, fijaron los precios de la materia prima y fiscalizaron el acopio. Aunque la situación mejoró, las crisis continuaron ocurriendo cíclicamente aún después de 1966, cuando se prohibieron las importaciones.

En el marco de las reformas neoliberales implementadas entre 1989 y 2001, el Estado desreguló el circuito productivo, lo cual desencadenó la crisis más grave de la historia del sector, provocando el desplome de los precios de la hoja verde, la desaparición de miles de productores y la concentración del grueso de la renta en seis cadenas comerciales y cuatro empresas yerbateras. Los reclamos de los agricultores determinaron que en 2002, en vísperas del modelo neodesarrollista (2003-2015), el Estado volviera a regular el circuito productivo creando el Instituto Nacional de la Yerba Mate (INYM). Aunque sus políticas son similares a las de la extinta CRYM, el INYM no cuenta con un mercado concentrador y está cooptado por los intereses agroindustriales (Corbey, Koffman, Orso, Ribone, Rodríguez \& Uría, 2013). Sus precios oficiales no son representativos de los costos agrarios de producción, ni tampoco son respetados por secaderos y molinos. Así, el escenario de concentración económica y exclusión social legado por el neoliberalismo se profundizó, y continuó durante la actual fase de restauración neoconservadora (2016-2019).

Sin embargo, la persistencia de la crisis estructural de los pequeños agricultores no significa en modo alguno que la yerba mate haya dejado de ser un negocio rentable. Con niveles de consumo per cápita de siete kilogramos anuales por habitante, el producto es demandado por el $98 \%$ de los hogares argentinos y es la bebida más consumida del país, por encima de las bebidas alcohólicas y gaseosas. Misiones y Corrientes son los principales productores nacionales y mundiales, y pese a que se trata de un producto de sesgo mercado-internista, las exportaciones a Medio Oriente (Siria, Líbano, Emiratos Árabes, Israel, Egipto, etc.), Europa (Rusia, España, Italia, Francia), Asia (China, Taiwán) y Estados Unidos (California y Florida) han cobrado relevancia durante las últimas décadas, absorbiendo alrededor del 15\% de la molienda. Así, la yerba mate es uno de los principales complejos exportadores de Misiones y Corrientes, y genera una renta de 1000 millones de dólares anuales (Gortari, 2018) apropiada sobre todo por las cadenas de hipermercados, grandes molinos nacionales y el grupo sirio Kabour. 
A pesar de la riqueza generada, Corrientes y Misiones continúan siendo dos de las provincias más pobres y subdesarrolladas del país. En Misiones, por ejemplo, el 28,1\% de la población no accede al agua potable de red, el 81,4\% carece de cloacas y el 36,4\% no cuenta con obra social. Según el último Censo de Población, Hogares y Viviendas realizado en 2010, el 15,6\% de los hogares misioneros estaba sumergido en la pobreza estructural —necesidades básicas insatisfechas (NBI)—, lo cual supera ampliamente el promedio nacional $(9,1 \%)$. Adicionalmente, se han registrado picos del $22,5 \%$ en ciertos departamentos. En los distritos yerbateros correntinos esa proporción oscilaba entre el $14,2 \%$ y el $16,9 \%$. En ambos casos, las tasas de mortalidad infantil eran altas, y se situaban en el 10,4 por mil y 14,9 por mil, respectivamente (MECON, 2015a; 2015b; DINREP, 2014). En ese adverso contexto, y al igual que los mensúes de antaño, los cosecheros de yerba mate son los más pobres entre los pobres.

\section{Del mensú al tarefero: COSecha de yerba mate y aCumulación Por DESPOSESIÓN EN EL NORDESTE ARGENTINO (1870-2018)}

\subsection{Los regímenes de reclutamiento y control de la fuerza de trabajo: intermediación laboral, trabajo esclavo y avasallamiento de derechos}

Desde un principio, la recolección de la yerba se basó en la violencia, la coerción y la esclavitud. En 1556, apenas dos décadas después de que los conquistadores españoles se instalaran en Asunción — la capital de Paraguay — para someter a los pueblos originarios, los encomenderos solicitaron a la Corona el monopolio de la explotación de los árboles de yerba mate y se repartieron 20000 nativos para su recolección (Gortari, 2017c). La creciente avidez por el «oro verde» rápidamente diezmó a los aborígenes, que perecieron ante la dura labor, el hambre, la mala alimentación, las enfermedades, los accidentes, el ataque de fieras y la represión de revueltas (Garavaglia, 1983; Ruiz de Montoya, 1639, citado por Gortari, 2017c).

Luego de la experiencia jesuita (1645-1768), que desarrolló la agricultura yerbatera y puso a los aborígenes bajo protección, en la región surgió un largo período lleno de convulsiones. Durante casi medio siglo (1801-1848), se sucedieron el saqueo de hacienda, la expropiación de tierras comunitarias por parte del gobierno paraguayo y los ganaderos de Corrientes y Rio Grande do Sul, la concesión de yerbales silvestres a la explotación privada, las guerras de independencia y las luchas intestinas por el dominio regional (Rau, 2012).

Sin perjuicio de la importancia de estos procesos, el factor de mayor desestructuración fue la Guerra de la Triple Alianza (1865-1870) librada por Brasil, Argentina y Uruguay contra el Paraguay. A su término, Misiones quedó bajo la jurisdicción de la provincia argentina de Corrientes, que en 1875 habilitó formalmente la explotación 
de los grandes yerbales silvestres y en 1881 privatizó 2,1 millones de hectáreas de tierras fiscales. Así, la tierra y el recurso cayeron en manos de compañías formadas por militares retirados brasileños y comerciantes argentinos (Alcaráz, 2014; Rodríguez, 2015) que luego formaron un oligopolio constituido por una docena de empresas, entre las cuales se destacaban la «Sociedad Industrial Paraguaya», la brasileña «Matte Larangeira» y las argentinas "Mascias», "Rodríguez y Cía.», «Escalada, Barthe y Arrillaga», «Núñez y Gibaja», «Martin y Cía.» y «La Plantadora».

En el ínterin, una masa de aborígenes y, en menor medida, criollos quedó violentamente desposeída de todo medio de producción y de vida, así como de todo lazo de sujeción personal, lo que conformó una suerte de "población flotante» (Rau, 2012). Debido a que las circunstancias de la época los empujaron a protagonizar un fenómeno cíclico de flujo y reflujo demográfico y desplazamientos pendulares de población en la lábil zona de la triple frontera, estos grupos sociales subalternos desarrollaron una conducta seminómade que planteó un problema estructural a los capitalistas yerbateros: cómo satisfacer su demanda laboral en un contexto signado por la escasez de potenciales obreros que, pese a no contar con más medios de subsistencia que la caza, la recolección y la agricultura itinerante, no se dirigían voluntariamente al mercado para ofrecer su fuerza de trabajo. La arquetípica figura del «mensú» y el reclutamiento basado en la intermediación laboral resolvieron ese dilema.

Con su principal centro de operaciones enclavado en la capital misionera (Posadas) y, en menor medida, Candelaria, Santa Ana y San Ignacio (Misiones) y Encarnación y Barracón (Paraguay) (Niklison, 1914), conchabadores ${ }^{3}$ pagados por las propias compañías reclutaban a peones correntinos, misioneros, entrerrianos y paraguayos (Barret, 1908) para destinarlos a los obrajes forestales y los yerbales silvestres. El mecanismo de reclutamiento consistía en un anticipo de dinero que, dejado a sus familias o gastado por el mensú en las tabernas y burdeles del barrio obrero de Posadas, lo encadenaba

\footnotetext{
3 Vulgarmente denominados «enganchadores», los conchabadores fueron una figura central para la formación de los mercados de trabajo rural de la Argentina a lo largo de todo el siglo XIX y buena parte del siglo XX, especialmente en aquellas regiones y actividades (ganadería vacuna en la pampa húmeda, cosecha de yerba mate y algodón en el nordeste, zafra azucarera en el noroeste, etc.) donde la fuerza laboral no abundaba. El concepto se refiere a aquellos agentes sociales (generalmente, propietarios de comercios, almacenes y tabernas, aunque también existían otros casos, como los de empresarios navieros e incluso personal militar) que se dedicaban a conseguir fuerza de trabajo para terceros mediante diversos mecanismos. Sobresalían, entre otros, las deudas por artículos de primera necesidad, bebida y juego, aunque debe señalarse que en ciertos casos el recurso a la violencia también estuvo presente. Considerados como el germen o antecedente histórico del actual contratista rural, los conchabadores por lo general obraban como nexos o intermediarios entre capitalistas y obreros, limitándose a reclutar y transportar trabajadores al lugar de producción sin intervenir directamente en las condiciones bajo las cuales se desarrollaba el régimen laboral. Aun así, en algunas actividades (la explotación forestal, por ejemplo) la frontera entre conchabadores y empresas era bastante difusa, a tal punto que la supuesta autonomía de tales contratistas o «enganchadores» era inexistente en los libros de contabilidad de las compañías.
} 
por contrato a los yerbales del Alto Paraná, hacia donde era transportado en buques bajo condiciones de hacinamiento, escasamente alimentado y durmiendo en el suelo (Niklison, 1914). Tal fue el destino sufrido por una masa laboral constituida por entre 15000 y 20000 personas (Barret, 1908).

Como bien señala Rau (2012), aquí la relación entre capital y trabajo se situaba en algún lugar entre la salarización y la esclavitud. Si bien los acuerdos laborales guardaban todas las formalidades jurídicas del moderno contrato salarial, bajo el modelo de "peonaje por deudas» la retención del mensú en el lugar de trabajo solo era viable por la vía de la coerción física. Por otra parte, la duración del contrato era indefinida en términos temporales y — como se verá más adelante- era extendida mediante mecanismos espurios que aumentaban artificialmente la deuda del trabajador $\mathrm{y}$, por ende, su tiempo de permanencia en el sistema. Según la tipología de Davie (citado por Bagú, 1969) sobre la esclavitud americana en los albores del capitalismo, es posible decir que el mensú era un híbrido: por un lado, se asemejaba a un indentured servant en lo que atańe a la firma de un contrato, pero no en otras condiciones ligadas a ese régimen, como la duración definida o la entrega de una parcela de tierra al término del acuerdo; por el otro, guardaba ciertas reminiscencias con el redemptioner o free-willer, puesto que trabajaba para saldar una deuda previamente contraída con su patrón.

Al mismo tiempo, dos factores determinaban que, en cierto modo, el mensú fuera un «siervo forzado" (forced into servitude) al estilo de los esclavos africanos. Por un lado, no siempre los mensúes eran reclutados vía contratos de endeudamiento, sino también a través del ofrecimiento de refugio, engaños y auténticas cacerías humanas (Barret, 1908). Por el otro, en ambos casos la función del agente de conchabo era similar a la del traficante de esclavos, pues no solo se encargaba de reclutar la «mercancía humana» requerida (la fuerza laboral) sino que además asumía la responsabilidad por su traslado hacia el sitio donde se hallaba el capitalista interesado en explotarla (Rau, 2012).

La hibridación entre esclavitud y capitalismo quedaba también plasmada en las formas de control y disciplina de la fuerza laboral. Al igual que las más mínimas infracciones disciplinarias, no alcanzar la productividad diaria fijada era motivo de multas y crueles castigos (azotes, cepo, latigazos, estaqueamiento ${ }^{4}$, etc.) (Barret, 1908). Exceptuando los pocos casos donde existieron motines y revueltas, la única forma de resistencia de los mensúes era la fuga. Para evitarlo, y pese a que las distancias y el aislamiento respecto de los centros poblados garantizaban la sujeción de los peones

\footnotetext{
${ }^{4}$ El estaqueamiento era un método de tortura que consistía en colocar al mensú en el suelo con sus cuatro miembros atados a estacas clavadas en la tierra, obligándolo a permanecer en este estado durante horas e incluso días enteros. Además de ocasionar atroces dolores derivados del forzamiento y descoyuntamiento de huesos, músculos y articulaciones, en ocasiones este suplicio era llevado a cabo sobre nidos de termitas blancas que previamente habían sido incendiados para que los insectos atormentasen al torturado (ver Barret, 1908).
} 
a los yerbales, el capital modificó los calendarios laborales. ¿¿De qué manera? Eliminando la práctica de suspender las faenas entre finales de agosto y comienzos de diciembre y licenciar durante ese lapso al personal (Barret, 1908), con lo cual el ciclo productivo (y la explotación laboral a este asociada) se volvió permanente. Nada constituía un cuestionamiento tan grave a la hegemonía del capital como la sustracción de fuerza de trabajo que la fuga encarnaba, razón por la cual los yerbateros buscaban por todos los medios recapturar a los peones evadidos u optaban por eliminarlos para así imponer un escarmiento que disciplinara al resto de su masa laboral (Alvira, 2009). Y en los pocos casos en que la fuga de los mensúes tenía éxito, esto tampoco garantizaba su libertad, existiendo casos en los que fueron recapturados cinco años después de haber escapado de los yerbales (Barret, 1908).

A finales del modelo agroexportador, el régimen productivo y laboral comenzó a mutar de la mano del avance de la agricultura yerbatera, que se consolidó recién en 1926, cuando un decreto presidencial obligó a colonos inmigrantes a plantar yerba en las parcelas concedidas como requisito para acceder al título provisional de la tierra. Cuatro años después, el Estado prohibió la explotación de los yerbales silvestres, que de todas maneras ya estaban muy deteriorados debido a la sobre explotación del recurso (Gallero, 2019). Así, los «mensúes» se convirtieron paulatinamente en "tareferos» o cosecheros.

Rau (2012) sostiene que, a partir de entonces, los anticipos, la retención forzosa de la fuerza de trabajo y el reclutamiento de peones a través de intermediarios desaparecieron. Sin embargo, esta afirmación es cierta solo en parte. En 1972, ya a finales del modelo de industrialización sustitutiva de importaciones, se reportó la existencia de algunos contratistas de fuerza de trabajo para la cosecha (Flood, 1972), y el Movimiento Agrario Misionero denunció que en ciertas zonas de la provincia el reclutamiento por endeudamiento operaba como un mecanismo de retención de trabajadores rurales (Báez \& Gortari, 2018). Es probable que la reaparición de estas estrategias haya obedecido a la escasez de tareferos que se registró hasta el momento en que la crisis yerbatera de 1966 y la prohibición estatal de levantar la cosecha ocasionaron un largo éxodo rural. Dado que las disposiciones de la Comisión Nacional de Trabajo Agrario habían colocado las levas de braceros bajo el control del Estado, esas prácticas de reclutamiento forzoso, contratación privada y peonaje por deudas claramente representaban una infracción a la legislación vigente.

Aun así, debe señalarse que se cumplían varios derechos garantizados por el Estatuto del Peón Rural de 1944 (decreto 28.169) y la ley 13.020 de 1947 —ley de los cosecheros-, como los descuentos para obra social, jubilación y adhesión sindical (Flood, 1972; Gortari, 2017b). No ocurría lo mismo, sin embargo, con el pago del salario familiar y los días feriados (Walsh, 1966). Esta problemática era invisible, en términos fácticos, para el Estado, dado que los tareferos eran el único sector del circuito yerbatero que no contaba con representación en el seno de la CRYM. 
Con el avance del neoliberalismo, la precarización se acentuó y extendió. La última dictadura militar (1976-1983) sancionó en 1980 la ley 22.248, que impuso un nuevo régimen de trabajo agrario que dejó a los peones rurales por fuera del amparo de la Ley de Contrato de Trabajo de 1974. Las sucesivas reformas laborales implementadas por el Estado nacional durante la década de 1990 alentaron la tercerización y la precarización en todos los sectores de la economía argentina, lo cual se combinó con la desregulación del circuito de la yerba mate y el estallido de la peor crisis de sobreproducción de la historia del sector. A partir de entonces, el otrora marginal papel de los contratistas rurales adquirió centralidad y la tercerización aumentó gracias a la aparición de firmas de servicios que reclutan fuerza de trabajo y negocian el precio de la cosecha y el flete con el propietario del yerbal o el secadero, para usar como variable de ajuste las condiciones laborales del tarefero y reteniendo como ganancia una parte de sus jornales (Gortari, 2013; Pereyra, 2013).

La creciente proliferación de la intermediación laboral obedeció básicamente a un fenómeno inédito hasta entonces: la sobreoferta de capacidad laboral para la cosecha (Rau, 2012), que en gran medida fue ocasionada por la crisis yerbatera de 1995-2001. Ante la brutal caída de su rentabilidad, muchos productores agrícolas perdieron o abandonaron sus chacras y se proletarizaron, a tal punto que la cantidad de unidades yerbateras se redujo un 49\% entre 1988 y 2002 (Rau, 2012). Numerosos campesinos debieron incursionar con más frecuencia en el mercado laboral para obtener recursos monetarios con los cuales reproducir sus economías familiares de subsistencia. Además, el desempleo rural creció aceleradamente en Misiones, sobre todo en el segmento de los asalariados permanentes sin lazos familiares con el productor, cuyo número se desplomó un 66,1\% entre 1988 y 2002 —de 13129 a 4454 trabajadores (INDEC, 1990; 2005)— debido a la mecanización de la cosecha de té y a que muchas empresas agroindustriales se desembarazaron de sus propias cuadrillas de cosecheros. La fuerza de trabajo estacional para la zafra yerbatera, en cambio, se mantuvo en niveles relativamente estables —entre 15000 y 17000 tareferos- (Rau, 2012; Traglia, 2014).

Por su parte, durante el momento más álgido de la crisis yerbatera muchos secaderos y molinos cerraron, en tanto que otros buscaron reducir costos desprendiéndose de su personal de más antigüedad, como capataces y administradores. Para ello, les anticipaban un pequeño capital de trabajo — el cual podía ser canjeado por la indemnización de rigor- para que se convirtieran en contratistas en los cuales externalizar el reclutamiento, traslado y administración de cosecheros y así eludir riesgos laborales (Slutzky, 2011; Rau, 2012; Ibarguren, 2017).

Buena parte de los trabajadores agrarios despojados de sus fuentes laborales emigraron a las pequeñas ciudades cercanas, lo cual determinó que entre 1991 y $2010 \mathrm{el}$ peso de la población rural misionera disminuyera del 37,46\% al 26,23\% de la población total de la provincia. Atraídos por la asistencia social alimentaria municipal, estos grupos 
sociales pauperizados se asentaron en la periferia de las pequeñas ciudades cercanas, lo que devino en la conformación de barriadas obreras que funcionan como verdaderos reservorios de fuerza de trabajo barata (Rau, 2012). Corroborando su condición de desposeídos, el $51 \%$ de estas familias carece de toda posibilidad de trabajar la tierra, en tanto que el 37\% directamente no tiene ningún acceso a la misma (Oscherow, 2017).

Como resultado, en un mismo acto de destrucción creativa el capital produjo tanto a su propio ejército de reserva como a los agentes de intermediación laboral destinados a explotarlo. Por un lado, la crisis yerbatera arrojó a numerosos trabajadores rurales fuera del sistema —así como también a pequeños productores agrícolas, induciendo su proletarización-, lo cual permitió que las compañías yerbateras contaran con una importante masa de fuerza laboral que, dada su estrecha dependencia de la zafra yerbatera para subsistir, estuviera siempre disponible para la acumulación bajo condiciones de abundancia relativa y bajo costo de reproducción. Por el otro, el capital simultáneamente diseñó la red de sub-contratación laboral necesaria para articular a ese ejército de reserva al mercado, red que, por otra parte, en gran medida está constituida por un segmento de esa misma masa de agentes sociales excluidos.

Conforme la precarización y el empleo informal avanzaban, los tareferos fueron por completo despojados de derechos laborales alcanzados medio siglo atrás, como jubilación, obra social, aportes patronales y seguros por riesgos de trabajo. Por otra parte, derechos históricamente incumplidos - aunque supuestamente garantizados por la ley 22.248, en ese momento todavía vigente- continuaron siendo sistemáticamente avasallados; entre ellos, se destacaban el pago del aguinaldo o sueldo anual complementario y las asignaciones familiares, así como el período vacacional y una indemnización inter-zafra equivalente al 5\% de los jornales.

Con el fin del neoliberalismo y el retorno a partir de 2002 de la intervención estatal en el circuito yerbatero, los gobiernos neodesarrollistas implementaron insuficientes cambios para paliar esa situación. Los trabajadores rurales comenzaron a contar con representación en el seno del INYM y en 2011 se sancionó el «nuevo» Estatuto del Peón Rural (ley 26.727), que impuso la formalización obligatoria de los cosecheros e implementó ciertos controles a través de la Administración Federal de Ingresos Públicos (AFIP) y el Ministerio de Trabajo.

Sin embargo, el éxito de esta política ha sido más nominal que real. Si en 2006 los niveles de informalidad en la cosecha de yerba mate eran del 65\% (Gortari, 2007), pocos años después ascendían al 80\% (Rau, 2012). El propio Ministerio de Trabajo admite que solo entre 5000 y 6000 cosecheros están registrados formalmente y que la mayoría carecía de cobertura social, fondo de desempleo, convenio colectivo y seguro por riesgos de trabajo. Según diversos relevamientos, entre el 70\% y el 77\% de los tareferos carecía de obra social y entre el 53\% y el $71 \%$ nunca había realizado aportes previsionales, cifra esta última que, de sumarse al $21 \%$ que alguna vez aportó, pero 
ya no lo hace, elevaría al 92\% la tasa de obreros sin proyección jubilatoria (Corbey, Koffman, Orso, Ribone, Rodríguez \& Uría, 2013; Oscherow, 2017; Gortari, 2018).

La continuidad de la informalidad laboral obedece a varios factores. En algunos casos, contratistas y productores agrícolas suelen mostrarse frontalmente reticentes al registro laboral. En otros, son los propios cosecheros quienes optan por no regularizar su situación para gozar de libertad para optar por trabajar en yerbales mejor mantenidos donde pueden obtener mayor productividad, contar con la posibilidad de vender su fuerza de laboral a empleadores que pagan jornales más altos y evitar descuentos por cargas sociales que a menudo incluyen beneficios que no pueden utilizar. Paradójicamente, el pago de las asignaciones familiares también desalienta la formalización del vínculo laboral. Dado que son percibidas estacionalmente —es decir, mientras dura la cosecha- y durante el resto del año desaparecen de los ingresos de los tareferos registrados, muchos cosecheros optan por mantenerse en el mercado informal, pues esto les permite cobrar ese beneficio estatal sin interrupciones como si fueran desocupados, independientemente de la estacionalidad de su inserción laboral. Con frecuencia, esta postura es inducida o reforzada por los propios productores yerbateros, quienes persuaden a los tareferos de mantener la relación laboral bajo condiciones de informalidad para que su condición de trabajadores registrados no les suponga un obstáculo para percibir dicho subsidio asistencial durante todo el período (Traglia, 2014).

Por otra parte, los mecanismos de coerción, disciplina laboral y retención en el lugar de trabajo continúan presentes bajo el actual régimen de subcontratación, aunque sin llegar a los extremos del pasado. Los «paros de cuadrilla» para renegociar del valor del jornal, antańo más frecuentes, son desalentados por el contratista mediante la automática pérdida del empleo y la interrupción inmediata del suministro de víveres en campamentos yerbateros que a veces se hallan a cien kilómetros o más del lugar de residencia del trabajador, lo que restringe, a su vez, su autonomía para salir voluntariamente de la relación laboral (Rau, 2012). Parafraseando a Marx (1968), la violencia ha sido reemplazada por la coerción sorda de las relaciones económicas.

Pero lo más llamativo es que la esclavitud lisa y llana tampoco ha desaparecido. En 2011, se reveló que Las Marías, la empresa yerbatera más grande del país, era la principal compradora de la hoja verde que la firma La Misionera cosechaba con fuerza de trabajo esclava en Colonia Caraguatay (Slutzky, 2011). Tres años después, el Registro Nacional de Trabajadores y Empleadores Agrarios (RENATEA) detectó casos de presunta trata laboral protagonizados por la compañía Yerbatera Misiones, que mediante engańos habría reclutado a 61 cosecheros en distintos puntos del país para luego trasladarlos a los yerbales de Parada Leis, donde se los explotaba laboralmente (El Territorio, 2015). Solo entre principios de 2014 y mediados de 2015 se efectuaron 32 presentaciones a la justicia misionera por trata laboral, todas ellas correspondientes al sector yerbatero (Misiones on Line, 2015). 


\subsection{Exprimiendo al cosechero: duración e intensidad de la jornada laboral}

Con respecto a la duración e intensidad de la jornada de trabajo, el régimen del mensú de un siglo y medio atrás y el del moderno tarefero sub-contratado guardan sugestivas semejanzas. Organizados en "comitivas" de entre veinte y treinta personas, los mensúes debían trabajar todos los días sin excluir domingos, feriados y jornadas lluviosas, así como también durante turnos nocturnos si las circunstancias climáticas lo permitín. Cada mensú debía recolectar diariamente no menos de ocho arrobas de hoja verde esto es, entre ochenta y noventa kilogramos, aunque algunas fuentes mencionan catorce y hasta dieciséis arrobas (alrededor de ciento cincuenta kilogramos) — y someterlas al proceso de zapecado o chamuscado en un fogón improvisado en la selva. Luego, debía arrastrar o cargar esa producción a lo largo de un trayecto de legua o legua y media —si las distancias eran mayores, se utilizaban mulas - hasta los centros de pesaje y luego iniciar la torrefacción o secanza de la yerba en «barbacuá». Este último proceso solía durar toda la noche, implicaba tareas adicionales (el acarreo de setenta u ochenta kilogramos de leña para alimentar el horno, por ejemplo) y exponía a los trabajadores a temperaturas superiores a los $70{ }^{\circ} \mathrm{C}$ que a veces los dejaban desmayados por el calor. Finalmente, debían realizar una molienda gruesa de la yerba y trasladarla a los depósitos de la empresa (Barret, 1908; Niklison, 1914; Alvira, 2009).

Con el lento paso de la extracción a la agricultura yerbatera, el sistema de 'comitivas' fue parcialmente abandonado y el cosechero pasó a ocuparse solo de recolectar y cargar la hoja verde, sin participar de su secado y primera molienda. Sin embargo, las jornadas laborales eran de doce e incluso catorce horas diarias (De Sagastizábal, 1984, citado por Gortari, 2017a). La tardía pero firme sindicalización de los trabajadores y las huelgas lanzadas en 1921 y 1928 (Rau, 2012) determinaron que en algunos años la duración de la jornada se redujera a ocho horas, aunque los momentos de represión

\footnotetext{
5 Se denomina barbacuá al sistema de secado tradicional utilizado desde hace siglos en las zonas de producción yerbatera. El origen etimológico de la palabra no está claro, atribuyéndose tanto a una corrupción fonética de la voz guaraní m barambacuá (literalmente, montón de hojas tostadas) como a una deformación del barbacoa caribeño. El barbacuá es una suerte de horno o parrilla circular o elíptica de siete metros de diámetro construida mediante estructuras rústicas con forma de cúpula o bote invertido sostenidas perimetralmente por columnas armadas con palos o varillas de madera, o bien con ladrillos. A doce metros del centro se sitúa la hornalla de la parrilla. A diferencia de los secaderos mecanizados, que completan esta etapa en una hora o menos, en el caso del barbacuá el secado puede demorar hasta doce horas y depende de la constante vigilancia del trabajador, quien está encargado de remover las hojas, extenderlas en capas a medida que van adquiriendo la consistencia deseada y alimentar con leña el horno, guiándose a lo largo de todo el proceso por el aroma, el color y la textura de las hojas. Lejos de desaparecer, este método artesanal actualmente continúa vigente en ciertas zonas yerbateras debido a que confiere un singular olor y sabor al producto. Debido a las altas temperaturas — entre sesenta y setenta grados centígrados en la parte superior de la estructura y entre ochenta y cien grados en su parte inferior-, el trabajo en barbacuá ha sido históricamente considerado insalubre (Forni, 2016).
} 
de la actividad gremial fueron aprovechados por las empresas para llevarla a nada menos que diecisiete horas diarias (Gortari, 2017b).

Recién en 1944 y 1947, cuando se dictaron el Estatuto del Peón Rural y la ley 13.020, respectivamente, la legislación fijó la duración de la jornada en nueve horas. Se impuso, además, el descanso dominical y condiciones razonables de higiene y alojamiento para los trabajadores rurales. Con respecto a esto último, nada cambió, puesto que los cosecheros siguieron siendo alojados en campamentos improvisados y transportados como hacienda de un yerbal a otro (Gortari, 2012). Tampoco puede decirse que los límites a la duración de la jornada laboral fueran siempre respetados. En 1972, por ejemplo, se reportó que el 47\% de los tareferos que recolectaban hoja verde en los secaderos yerbateros trabajaba más de nueve horas diarias (Flood, 1972; Gortari, 2017b). Dos años después, se denunció que en Corrientes el grupo Navajas Centeno Artaza, propietario de la megaempresa yerbatera Las Marías, obligaba a sus obreros a levantar la cosecha en turnos de doce horas diarias (Báez \& Gortari, 2018).

En la actualidad, ni la duración ni la intensidad del trabajo han disminuido para el tarefero reclutado bajo el régimen de sub-contratación. Para las cuadrillas formadas por entre veinte y treinta personas, la labor implica el acopio de pequeñas ramas de yerba sobre "ponchadas", esto es, mantas de arpillera que al ser recogidas en sus extremos forman los «raídos», bultos de cien a ciento veinte kilogramos (Roa, 2013) que son acarreados por los trabajadores por extensos trayectos hasta los camiones que los llevarán a los secaderos. Con un mínimo de nueve horas diarias, la jornada laboral puede extenderse a diez, doce o incluso catorce horas (Rau, 2012; Corbey, Koffman, Orso, Ribone, Rodríguez \& Uría, 2013; Haugg, 2016). De hecho, un relevamiento realizado en la tradicional localidad misionera yerbatera de Oberá determinó que el $74 \%$ de los tareferos trabajaba entre ocho y doce horas diarias y que el $12 \%$ lo hacía durante lapsos superiores a las doce horas (Aiani, 2017). Como se verá más adelante, esto se conecta con la problemática del salario del obrero.

Sin perjuicio de lo anterior, las variaciones en la duración de la jornada laboral obedecen también a dos factores adicionales: la estación del año, que determina la cantidad de horas de luz natural; y la distancia existente entre el lugar de residencia de los trabajadores y los yerbales. Si el yerbal es relativamente cercano, el contratista recoge a los trabajadores a las 4:00 o 5:00 a.m. y los devuelve a sus domicilios al oscurecer. Si la chacra queda a una distancia inconveniente para el contratista, los tareferos (y muchas veces sus familias completas) deben cambiar temporariamente de residencia durante un lapso de quince a treinta días, alojándose a la intemperie o bajo carpas improvisadas de polietileno negro. Se estima que el $23 \%$ de los trabajadores es sometido a esta modalidad. En este último caso —al cual los cosecheros suelen considerar como la peor opción laboral—, la eliminación del tiempo de traslado al lugar de trabajo resulta en la ampliación de la jornada de trabajo y la supresión del descanso dominical (Rau, 2012). 
Esto último quedó expuesto en 2013, cuando una inspección laboral determinó que en la localidad misionera de Andresito el grupo sirio Kabour cosechaba yerba mate obligando a los tareferos a trabajar de lunes a lunes (Misiones on Line, 2013).

En esos casos, las condiciones son tan precarias como cabe imaginarlo. Los cosecheros quedan expuestos a las inclemencias climáticas —entre ellas, las prolongadas lluvias invernales-, duermen en colchones tirados en la tierra y carecen de baños, agua potable, cocina, electricidad, asistencia médica y comunicaciones (Corbey, Koffman, Orso, Ribone, Rodríguez \& Uría, 2013; Gortari, 2013). Todo esto, además de violar flagrantemente derechos garantizados por ley — como el acceso a agua, higiene y una vivienda digna en la chacra durante la zafra-, no es demasiado distinto de lo que ocurría durante la época de los mensúes, cuando los peones vivían a la intemperie y dormían en el suelo, apenas guarecidos por toldos improvisados con ramas y hojas.

\subsection{Salario y fraude: la remuneración por debajo del nivel de subsistencia y la expropiación de la capacidad de consumo del obrero}

Siguiendo a Marini (1991), otro rasgo típico de la súper explotación laboral son los salarios fijados por debajo del nivel de subsistencia. En el caso de la yerba mate, el hecho de que las remuneraciones del cosechero sean inversamente proporcionales a la rigurosidad de las faenas realizadas se ha configurado en una constante secular. Sometido a un régimen de pago a destajo, cada mensú de los poco más de ochocientos que a comienzos del siglo XX contrataban las empresas que operaban del lado argentino obtenía en 1914 solo treinta pesos cada cien arrobas de yerba. Considerando la producción mensual individual promedio — doscientas a trescientas arrobas-, esta cifra arrojaba como resultado una remuneración máxima de noventa pesos al mes (Niklison, 1914).

No menos importante, esos guarismos eran meramente nominales, puesto que las empresas se valían de diversos mecanismos para expropiar al peón de su capacidad de consumo. El costo de vida en los yerbales era muy elevado y se combinaba con reiteradas estafas y pagos con vales. Para empezar, era habitual que se defraudara al mensú en el pesaje, argumentando la mala calidad de la producción o simplemente alterando la balanza (Alvira, 2009). Como resultado, y dado que los ingresos y gastos del mensú se anotaban sin ningún control, fiscalización ni objeciones de su parte —algo que en parte era facilitado por su extremadamente bajo nivel de instrucción-, rara vez los peones yerbateros lograban saldar sus deudas. Por lo general, los pagos se realizaban en vales que eran únicamente canjeables en las proveedurías de los campamentos yerbateros, lo cual convertía a los mensúes en víctimas de una doble expoliación: las ventas a crédito y los altos precios de los artículos de baja calidad de las proveedurías, que triplicaban y hasta septuplicaban su valor real. Es importante señalar que las empresas 
no proporcionaban las herramientas de trabajo a sus obreros, sino que estos debían adquirirlas en los campamentos yerbateros. A la luz de esa situación, es fácil colegir que la expoliación de sus remuneraciones debió haber sido aún más pronunciada.

La alimentación proporcionada a los trabajadores era cara, escasa y fisiológicamente insuficiente para compensar la ruda labor realizada. Por lo general, era de pésima calidad y se componía de maíz, porotos negros, charque de yegua, sebo y «reviro» —una pasta de harina y grasa—, siendo frecuente que incluyera alimentos en estado de descomposición (Barret, 1908; Alvira, 2009). Los niveles de crueldad de los empresarios yerbateros eran tales que los contratos expresamente impedían a los mensúes abandonar el campamento aun cuando no hubiese víveres (Niklison, 1914).

Todo lo previamente seńalado explica que en 1914 un obrero soltero gastara entre dieciocho y veinticinco pesos mensuales, y que el costo de vida para un peón con familia ascendiera a entre 30 y 35 pesos al mes (Niklison, 1914). Recordando que la remuneración de cada mensú alcanzaba, en el mejor de los casos, los noventa pesos mensuales, las cifras previamente expuestas implican que el capital le arrebataba entre el 20\% (18 pesos) y casi el $40 \%$ (35 pesos) de sus magros ingresos. De los datos de Barret (1908) se desprende una expoliación todavía mayor, cercana al 80\%. Las remuneraciones se abonaban en moneda nacional de curso legal solo en los raros casos en que el trabajador llegaba al fin de la temporada con saldo positivo (Alvira, 2009). A raíz de este conjunto de exacciones, el mensú siempre se hallaba cerca —o por debajo— del límite de la más básica reproducción de su fuerza de trabajo. Esto también permite comprender por qué las empresas yerbateras de la época lograron amasar verdaderas fortunas en muy corto tiempo. Recurriendo una vez más a los datos de Barret (1908), puede colegirse que los costos de producción (denominados en pesos papel) rondaban el $7 \%$ del precio final de venta del producto (fijado en oro), generando utilidades del $44 \%$.

A mediados de la década de 1940, la legislación laboral protectora de los gobiernos populistas de la época estableció algunos beneficios para los trabajadores rurales, tales como salarios mínimos, vacaciones pagas y aumentos salariales para los obreros a destajo, así como también controles y rebajas de los precios de las mercancías vendidas en las proveedurías. Sin embargo, los fraudes continuaron. De las referencias de Gortari (2012) a las «tramposas balanzas de los productores yerbateros» se desprende que durante este período los tareferos no gozaron de los privilegios otorgados por la ley 1.071/1949, que en el caso de la zafra azucarera evitaba el pesaje fraudulento de materia prima mediante la obligatoriedad de la instalación de básculas controladas por los sindicatos. Según el ya citado estudio de Flood (1972), que relevó las condiciones laborales de los cosecheros en los departamentos de Eldorado, Oberá y San Ignacio, Apóstoles, Montecarlo y Cainguás, en todos los casos la retribución pagada por kilogramo de hoja verde recolectado se situó por debajo de los valores fijados por la Comisión Nacional de Trabajo Rural. Peor aún, no solo no se pagaban los días feriados, ni aguinaldos ni 
salarios familiares, sino que además el $48 \%$ de los tareferos recibía parte o toda su paga en mercadería y/o vales canjeables en los almacenes de las chacras, cuyos sobreprecios los despojaban de más del 40\% de sus ingresos (Flood, 1972; Gortari, 2017b).

Durante la década neoliberal de 1990, la crisis yerbatera y el desplome de la rentabilidad agrícola sumergieron las remuneraciones de los tareferos por debajo del umbral de la subsistencia. Esto fue facilitado por la convergencia de tres factores: en primer lugar, la existencia de un ejército de reserva de fuerza de trabajo rural desocupada que presionó hacia abajo los jornales de los cosecheros; a lo anterior se suma el avance de la informalidad laboral, que permitió el pago de remuneraciones inferiores a las fijadas por los organismos estatales de contralor; $y$, finalmente, las nuevas prácticas de recolección de materia prima impuestas por la agroindustria, que suplantaron la antigua modalidad de cosecha de la planta entera por el descarte de palos y semillas, determinando que la retribución por tiempo de trabajo fuera menor (Rau, 2012) y que el tarefero debiera extender su jornada laboral para obtener el mismo ingreso que antes.

Como resultado, los jornales descendieron entre 1993 y 1998 de treinta a dieciocho centavos de peso por kilogramo de hoja verde (Rau, 2012). Considerando que, durante la época de zafra, debido a cuestiones climáticas y de salud, un tarefero puede trabajar quince días al mes y recoge una media de 450 kilogramos de yerba (Gortari, 2018), sus ingresos mensuales cayeron de 135 a 90 pesos por mes. Eso significa que su salario, que en 1993 se situaba un 32,5\% por debajo del valor fijado por el Consejo Nacional del Salario Mínimo, Vital y Móvil (doscientos pesos durante toda la etapa), a partir de 1998 resultó un 59,5\% inferior a ese parámetro.

Paralelamente, los abusos del pasado (endeudamiento, anticipos, proveedurías) se intensificaron a tal punto que los propios cosecheros comenzaron a reconocer semejanzas entre su situación y la de los mensúes de principios del Siglo XX. Además de la entrega por parte del contratista de mercaderías como adelanto y del descuento de las provisiones consumidas en los yerbales, a menudo el saldo de la remuneración laboral era abonado en mercaderías al final de la quincena, lo cual acentuaba la dependencia del asalariado, restringía su libertad de consumo y abarataba el salario por medio de sobreprecios (Rau, 2012).

Pese a las regulaciones estatales instauradas a partir de 2011 por las políticas neodesarrollistas, las remuneraciones continuaron siendo bajísimas. Para el raro caso de un tarefero formalizado, el salario bruto promedio rondaba en 2012 los 2865,92 pesos mensuales, de los cuales -una vez descontado el 20\% de aportes- solo percibía 2.293 pesos (Corbey, Koffman, Orso, Ribone, Rodríguez \& Uría, 2013). Como resultado, durante el período de zafra el ingreso mensual de la familia del cosechero yerbatero se situaba un $14,1 \%$ por debajo del salario mínimo, vital y móvil de ese año (2.670 pesos). Más recientemente, en 2018, la remuneración mensual promedio de un tarefero ascendía a 10125 pesos, cifra casi equivalente al salario mínimo (10 700 pesos) 
y apenas suficiente para que su grupo familiar — formado por una media de seis integrantes - adquiriera la mitad de la canasta básica de bienes y servicios (21 134 pesos) (Gortari, 2018) teóricamente necesaria para la manutención de una familia de cuatro miembros. No es extraño entonces que entre 2012 y 2018 la participación del tarefero en el precio final del producto fluctuara entre el 1,31\% (Traglia, 2014) y el $4,5 \%$ (Gortari, 2018). Según este último autor, en solo media hora de trabajo el tarefero recolectaba materia prima por un valor equivalente a su salario diario; el resto de la jornada lo dedicaba a generar un excedente para contratistas, agricultores, secaderos, molinos, comercios y el fisco.

Es importante señalar que las estimaciones citadas parten del improbable supuesto de que las disposiciones estatales respecto de los jornales de los trabajadores rurales estacionales se cumplan. En 2018, los propios tareferos denunciaban que en plena cosecha percibían solo 300 pesos diarios, cifra que, en el hipotético caso de que pudieran trabajar 20 días al mes, se traduciría en salarios de 6000 pesos — un 43,9\% por debajo del salario mínimo, vital y móvil-.

Por añadidura, el cosechero es objeto de múltiples expropiaciones. Con respecto a los escasos tareferos formalmente registrados, se han reportado casos de productores y contratistas que se apropiaban fraudulentamente de los aportes para jubilación y obra social o que no les pagaban sus salarios a cambio de abonarles los aportes patronales durante todo el año, amén de emitir recibos de sueldo irregulares que no detallaban ni el volumen de hoja verde recolectado ni los descuentos realizados. Tampoco existen controles sobre el volumen cosechado, cuya estadística depende del capataz o contratista. Incluso el propio Estado contribuye a despojar a los cosecheros de parte de sus jornales, dado que la normativa vigente establece que el monto de las asignaciones familiares disminuya según la productividad del trabajador aumenta, erosionando su remuneración (Corbey, Koffman, Orso, Ribone, Rodríguez \& Uría, 2013; Traglia, 2014; Ibarguren, 2017).

La mayor presencia del Estado tampoco ha desterrado prácticas arquetípicas de la relación laboral, como la adjudicación de deudas inexistentes, el pago en especie, la venta a precios abusivos de bienes, alimentos y herramientas luego descontados de la paga semanal y el aumento del endeudamiento en el lugar de trabajo (Pereyra, 2013). Si bien el censo de tareferos realizado en 2010-2011 determinó que el $97 \%$ de los cosecheros recibía su jornal en efectivo y apenas un 3\% hacía lo propio en vales o mercadería, lo cierto es que los medios de trabajo, el polietileno para improvisar el campamento, la comida y los enseres para cocinar deben ser adquiridos al ingresar al yerbal o de manos del propio contratista (Gortari, 2017b; 2018; Ibarguren, 2017). A propósito de la alimentación, la dieta actual es, desde el punto de vista nutricional, tan pobre la de los mensúes de antaño: chipá amasada y 'reviro' con harina, aceite, grasa y apenas algo de carne (Haugg, 2016). 


\subsection{El peor de los despojos: trabajo infantil y desposesión del derecho a la salud}

El régimen laboral del mensú constituyó un ejemplo paradigmático de lo que en otro lugar se ha denominado «desposesión del derecho a la salud» (Gómez Lende, 2015). Los accidentes por traumatismos y enfermedades infecciosas, venéreas, orgánicas y ocupacionales como la diarrea, la disentería, el paludismo, la desnutrición, la sífilis, la tuberculosis, la anquilostomiasis, el bocio y la «buba» de los yerbales eran frecuentes (Alvira, 2009). Las condiciones de vida eran tan miserables que apenas el 10\% de los niños nacidos en los yerbales alcanzaba la edad adulta (Barret, 1908), en tanto que, al cabo de diez, doce o a lo sumo quince años de penalidades en la selva, el desgaste físico de los pocos mensúes que sobrevivían al régimen laboral de la extracción yerbatera era tal que sus únicas opciones para subsistir eran mendigar, enrolarse como cocineros en las "comitivas" o establecerse como bolicheros en los centros de conchabo (Niklison, 1914). Peor aún, si debido a accidentes o patologías el peón se veía impedido de trabajar durante algunos días, en el ínterin debía pagar por su manutención en el campamento, no contando con medicinas básicas ni asistencia médica ni hospitalaria alguna por estar endeudado con la patronal (Niklison, 1914). Esto no impedía que esta última le efectuara descuentos que registraba en su libreta de conchabo bajo el eufemismo de atención médica o cuota de sanidad (Alvira, 2009).

Por otra parte, cabe destacar que el trabajo infantil era extremadamente habitual, siendo frecuentes las levas de niños de nueve años que al cumplir los veintitrés mostraban los signos del prematuro envejecimiento derivado de la dura vida en los yerbales. A comienzos del siglo XX, un censo oficial de la población obrera de la localidad misionera de Santa Ana no registró la presencia de varones menores de dieciséis años porque todos estaban contratados en los campamentos del Alto Paraná (Niklison, 1914). Inclusive, algunas estimaciones señalan que el $70 \%$ de los arreados a los yerbales eran menores de edad (Barret, 1908). Su función dentro del proceso productivo consistía en desgajar y zapecar la yerba, ordenar los bultos a acarrear y guiar a las mulas que transportaban las cargas más pesadas. Sometidos a las mismas jornadas y disciplina que los adultos, privados de cualquier tipo de instrucción elemental y expuestos a los mismos riesgos que el resto de la fuerza laboral, los niños podían pasar casi toda su vida activa en el Alto Paraná (Alvira, 2009).

El trabajo infantil en los yerbales nunca desapareció. A mediados del siglo XX, en plena vigencia de la legislación laboral que protegía a los trabajadores rurales, era habitual que los cosecheros se desplazaran a las chacras con sus mujeres y niños para de ese modo aumentar su productividad (Gortari, 2012). La situación cobró estado público en 1966, cuando se denunció la explotación de menores de doce años (Walsh, 1966).

Desde la crisis de la década de 1990 en adelante, el trabajo infantil se ha convertido en la regla. De hecho, la edad de inicio en la cosecha de yerba mate oscila entre los 
catorce y los apenas cinco ańos, y aproximadamente el 10\% de los tareferos registrados — sin contar a los informales - está constituido por individuos menores de dieciocho años (Corbey, Koffman, Orso, Ribone, Rodríguez \& Uría, 2013). Si bien en 2008 se sancionó la ley 26.390, que prohíbe el trabajo infantil, las contradicciones del nuevo régimen de trabajo agrario vigente desde 2011 facilitan la trasgresión de la norma. Siguiendo la tesitura de la ley 22.248 sancionada por la última dictadura militar, el nuevo Estatuto del Peón Rural prohíbe que menores de dieciséis años desarrollen labores fuera de la unidad doméstica o chacra familiar — siempre que se respete el límite horario y no afecte la escolaridad-, pero a la vez habilita a jóvenes de entre dieciséis y dieciocho años a celebrar contratos de trabajo agrario, en tanto cuenten con el conocimiento y consentimiento de sus padres.

Pese a la tipificación de estas prácticas como delito penal, también es habitual la contratación indirecta de niños de entre nueve y doce años que acompañan a sus padres como 'ayudantes' en la tarea, o que trabajan con ellos en 'duplas' para la recolección de hoja verde. En el poco probable caso de que el tarefero adulto esté registrado formalmente, no ocurre lo mismo con el niño o joven, que no está asegurado por las cargas sociales y la cobertura sanitaria. Si bien el trabajo infantil es justificado por los productores agrícolas y sus propios progenitores como una forma de reproducción de valores sociales que realza el papel de la incursión temprana en el mundo laboral para la formación y educación para la vida, esa visión naturaliza o invisibiliza la funcionalidad del trabajo infantil para la subsistencia de familiar. Según datos de Re (2015), la dupla padre-hijo permite que el ingreso familiar diario sea un 60\% más alto que si la cosecha fuera realizada individualmente por el progenitor.

Paralelamente, la desposesión del derecho a la salud continúa vigente. La cosecha es una labor que rápidamente desgasta el cuerpo de los cosecheros y lo despoja de su fuerza vital (Roa, 2013). De acuerdo con distintas fuentes, el constante acarreo de bultos pesados, las largas posturas inclinadas durante la recolección, las condiciones de transporte a los yerbales, la exposición a alimańas y condiciones climáticas adversas (lluvia, heladas, sol, calor, frío) y otros factores son causantes de un sinnúmero de malestares y enfermedades, a tal punto que los trabajadores envejecen precozmente a los cuarenta años. Las patologías más leves incluyen cefaleas, insolaciones, heridas en los ojos, dolores de cintura y columna y resfríos y gripes, hasta llegar a problemas mucho más graves, como la artritis reumatoide, la artrosis, las hernias de discos intervertebrales, las fracturas óseas e incluso el cáncer de estómago provocado por el consumo de agua contaminada con agrotóxicos (Roa, 2013; Traglia, 2014; Pereyra, 2013; Re, 2015; Gortari, 2018).

En los pocos casos en que estos trabajadores están registrados formalmente, sus enfermedades no se consideran de origen ocupacional y el aporte a la obra social es insuficiente, contando solamente con la asistencia sanitaria pública. Habituados al rigor 
de su labor, los tareferos recién perciben que están enfermos cuando no pueden ir al yerbal, con lo cual son relevados por sus hijos y el círculo vicioso se repite indefinidamente (Roa, 2013). Asimismo, no pocas veces los trabajadores fallecen debido a los siniestros viales sufridos por los camiones que, como si fueran hacienda, los trasladan precariamente a los yerbales. Solo entre 2008 y 2013 estos accidentes se cobraron veinte víctimas fatales, por no mencionar a los muertos y heridos graves en las chacras y fincas yerbateras, entre los cuales se cuentan niños (Gortari, 2013).

\section{El papel de la politica: la connivencia estatal con la súper explotación laboral}

Harvey (2004) sostiene que la acumulación por desposesión siempre requiere de la intermediación y el beneplácito del Estado, quien recurre a su monopolio sobre la definición de la legalidad y sobre el aparato represivo para legitimar e incluso promover el despojo. Las dinámicas de súper explotación laboral en la cosecha de yerba mate no han sido históricamente ajenas a esa realidad. Como señala Rau (2012), para que el régimen de expoliación de los mensúes se sostuviera en el tiempo, la existencia de una masa de desposeídos de medios de producción y vida era una condición necesaria pero no suficiente; también era primordial la intervención de instituciones sociales reguladoras que velaran por la reproducción de estas relaciones de producción. Así, la connivencia del poder político, judicial y policial de la provincia de Corrientes y del entonces Territorio Nacional de Misiones permitió que los empresarios yerbateros lograran imponer sus abusivas prácticas laborales sin resistencia.

Por acción u omisión, el aparato estatal siempre fue cómplice de las empresas con respecto a sus prácticas de retención de la fuerza de trabajo; de ahí que los asesinatos impunes fueran bastante frecuentes cuando los mensúes escapaban antes de que su 'contrato' finalizara. En 1907, por ejemplo, siete obreros -uno de los cuales era un niño- fueron masacrados por fugarse de yerbales de Misiones (Barret, 1908). Dado que la magistratura territorial asentada en la capital misionera era básicamente corrupta, en algunos casos estos hechos de sangre llegaron a comprometer a jueces e incluso al cónsul brasileño en Posadas (Gortari, 2017b; Alcaráz, 2014; 2019). La situación es comprensible cuando se advierte que funcionarios y magistrados poseían inocultables vínculos con las principales empresas yerbateras de la época y que en ciertos casos estas últimas pertenecían a poderosas familias de la política local y nacional, como Barthe, Roca y Lanusse. Esto también explica la escasa eficacia de las escasas iniciativas estatales orientadas a contrarrestar el brutal dominio de las compañías, como la ordenanza de 1903, que ínfimamente reguló el ejercicio de la prostitución, uno de los principales mecanismos de reclutamiento del mensú (Alcaráz, 2014; 2019).

Aunque el paso del extractivismo a las colonias agrarias determinó que las compañías ya no contaran con el aislamiento de la selva para ocultar sus crímenes (Alvira, 2009), 
la mimetización entre el poder político y corporativo y su connivencia de intereses con el avasallamiento de los derechos laborales de los tareferos son dos fenómenos que se han mantenido prácticamente intactos hasta la actualidad.

Quizás el ejemplo más paradigmático lo constituya el yerbal I' Porá, localizado en Parada de Leis y perteneciente a Yerbatera Misiones, empresa ya mencionada debido a sus presuntas actividades de trata laboral. El principal accionista de la empresa es Ramón Puerta, quien durante la década de 1990 fue gobernador de Misiones, luego se desempeńó como senador nacional, y a comienzos del siglo XXI llegó a detentar durante un breve lapso la presidencia de la república. Propietario del campo donde se realizaba la cosecha y del secadero al cual iba destinada la materia prima recolectada, este conocido dirigente provincial y nacional mantenía a más de medio centenar de trabajadores —entre ellos, a seis menores de edad — en condiciones infrahumanas. Los tareferos vivían bajo lonas de plástico, dormían en colchones en la tierra, no contaban con baños, agua potable, energía eléctrica ni atención médica y se alimentaban con comida en estado de descomposición. Sus jornadas laborales se iniciaban a las 5:00 am y culminaban a las 7:30 pm, con jornales que, en los pocos casos en que fueron abonados, no llegaban a los 1.500 pesos por quincena (El Territorio, 2015; Misiones on Line, 2014; 2015).

Casi sin matices, la misma lógica se repetía en el también mencionado caso de la empresa La Misionera en Colonia Caraguatay. La compañía pertenecía a Justo Ramírez Acosta, concejal del municipio de la citada localidad y propietario del supermercado donde los trabajadores debían canjear los vales que recibían como parte de sus míseras remuneraciones. A propósito de sus jornales, en los contados casos en que se pagaban en efectivo los mismos ascendían - extremando el esfuerzo y restringiendo los gastos de comida en el campamento- a apenas 120 pesos semanales, cifra irrisoria teniendo en cuenta que la Comisión Nacional de Trabajo Agrario había fijado para ese año un jornal diario de 90,59 pesos (Rivas Zelaya, 2011).

Por otra parte, las políticas asistenciales del Estado paradójicamente garantizan que esta fuerza de trabajo continúe siendo explotada por debajo del umbral de la subsistencia. Hasta 2009-2011, los cosecheros alternaron entre un período de cinco a ocho meses de ocupación con supervivencia apenas garantizada y una fase de desempleo o retorno al ejército de reserva laboral que, solo interrumpida por ocasionales trabajos precarios estacionales, implicaba obvias dificultades para alimentar a sus familias (Rau, 2012). Desde entonces, el tarefero teóricamente pasó a contar con la posibilidad de acceder al Subsidio Interzafra — que le proporciona ingresos bajos pero estables—, así como al Bolsón de Alimentos y la Asignación Universal Por Hijo.

Aunque inobjetables a la hora de reducir ligeramente la brecha estacional de ingresos del tarefero entre la cosecha y los 'tiempos muertos' del período interzafra, promover la escolaridad de los niños y constituir a veces el único ingreso monetario con el que cuentan esas familias durante gran parte del año, estos recursos estatales 
no atacan la raíz del problema. Por el contrario, lo perpetúan, puesto que subsidian indirectamente a los empresarios al costear con fondos del erario público parte de las remuneraciones que deberían ser pagadas por los productores agrícolas, los secaderos y los contratistas, según el caso.

Asimismo, estos paliativos muy lejos están de garantizar una vida digna para los tareferos. Casi sin excepción, dichas políticas están dirigidas a los cosecheros registrados formalmente; así, la gran mayoría queda excluida de sus beneficios. Según el ya mencionado censo de tareferos, solo el 6,7\% cobraba el Subsidio Interzafra y el $29 \%$ recibía ayuda alimentaria, en tanto que el $97,7 \%$ no era beneficiario de ningún programa estatal para la pobreza (Oscherow, 2017). La situación empeoró a partir de 2017, cuando en el marco del ajuste dispuesto por el gobierno neoconservador de turno el Estado decidió retirar buena parte de la ayuda alimentaria y asistencial que hasta ese momento otorgaba a los tareferos (Palmbaum, 2017), con lo cual los trabajadores volvieron a depender casi exclusivamente de la política salarial privada de la patronal yerbatera. Dos años antes, el gobierno nacional había eliminado el RENATEA, principal impulsor de las denuncias de trabajo esclavo e infantil en el sector rural.

\section{Conclusiones}

Basada en la depredación, el fraude y distintas formas de violencia material y simbólica, la llamada acumulación primitiva ha continuado operando, a veces solapadamente, en otras ocasiones de modo más evidente, como una fuerza estructural del capitalismo en Misiones y el nordeste correntino. Corroborando ese supuesto a través de un análisis histórico comparativo, el presente trabajo ha puesto en evidencia tres cuestiones relevantes: en primer lugar, las paupérrimas condiciones de vida y trabajo de la fuerza de trabajo estacional del sector yerbatero de la región; en segundo término, la tendencia a que la extracción de plusvalía en el sector se aparte con frecuencia de la reproducción ampliada del capital y la explotación «normal» del proletariado para descansar sobre relaciones de trabajo parcial o totalmente basadas en diversas dinámicas expropiatorias; y finalmente, la transversalidad secular de ciertas prácticas sociales, demostrando que estas no obedecen a herencias semi-feudales, sino a la lógica del propio sistema capitalista.

Más importante aún, el artículo muestra cómo el capital se ha asegurado la constante reproducción estructural del proceso mediante la adaptación de sus dispositivos expropiatorios a las circunstancias sociales e históricas de los distintos modelos de acumulación. Así, los convulsos acontecimientos políticos, sociales, militares y económicos de la segunda mitad del siglo XIX derivaron en la desposesión violenta de un sector de la población de la región de todo medio de producción y de vida, convirtiéndola en fuerza de trabajo potencial para el extractivismo yerbatero de la época que, debido a sus características semi-nómades, fue forzada a ingresar a las nuevas relaciones sociales 
de producción. Un siglo después, la crisis yerbatera desencadenada a mediados de la década de 1990 generó lo inverso: un vasto ejército de reserva de fuerza de trabajo geográficamente estable que, dadas sus precarias condiciones de vida, el carácter estacional de la zafra y la ausencia de otras opciones laborales, pugna ansiosamente por ser reclutado por el capital. En un caso, la sujeción de la fuerza de trabajo al capital se basó en la coerción y el crimen; en el otro, quedó sujeta a una lógica del mercado que tornó innecesario recurrir a la violencia para garantizar la disciplina laboral. Ambas situaciones, empero, derivaron en fenómenos muy similares de acumulación por desposesión.

Iniciándose con los conchabadores pagados por las propias compañías yerbateras para la leva de mensúes hasta llegar a los actuales contratistas rurales que reclutan tareferos, la intermediación laboral se revela claramente como una variable transversal a ambos modelos. Sin embargo, existen dos diferencias importantes. Por un lado, en el régimen del mensú existían contratos que formalizaban las relaciones entre capital y trabajo - lo cual es paradójico, teniendo en cuenta que ese mercado laboral se hallaba aún en etapa de formación-, mientras que en el modelo actual ese vínculo rara vez está legalmente homologado. Por otra parte, en el primer caso el papel del intermediario se limitó a encadenar al trabajador mediante el peonaje por deudas sin intervenir en el proceso productivo, mientras que en el segundo es el contratista (y no la empresa yerbatera) quien fija directamente las condiciones laborales.

Por lo demás, no existen contrastes sustanciales. El transporte en condiciones infrahumanas en barcos a vapor ha dejado paso al traslado precario y de alto riesgo en camiones, en tanto que el alojamiento a la intemperie ha sido sustituido por campamentos improvisados con carpas de polietileno y colchones en el suelo. Si a lo anterior se le añade el hecho de que el modelo contemporáneo de explotación supone el recorte legal y el incumplimiento factual de derechos sociales y laborales inexistentes en la época de los mensúes y parcialmente garantizados por la tutela estatal durante las décadas previas a la desregulación yerbatera, debe admitirse que el régimen actual supone un retroceso a la desprotección laboral del pasado, lo cual implica la inutilidad de las normas establecidas por la legislación vigente.

Sin la crudeza de las cacerías humanas de un siglo y medio atrás, las prácticas linderas con la semi-esclavitud, el reclutamiento mediante el engaño y la trata laboral continúan presentes, en mayor o menor grado. Por otra parte, dinámicas de expoliación claramente reñidas con la relación salarial típica — adelanto de mercancías, pago en especie, descuento del precio inflado de las provisiones consumidas en los yerbales y del valor de los medios de producción, endeudamiento (real o ficticio) en el lugar de trabajo, etc. - se desarrollan rampantes, agravadas por el surgimiento de otros mecanismos de fraude - la apropiación por parte del capital de aportes previsionales y el canje de salarios por contribuciones patronales—. Ni la duración ni la intensidad de la jornada laboral han sufrido cambios significativos, en tanto que las remuneraciones continúan 
manteniéndose por debajo del nivel de subsistencia, aseguradas ya no por la coerción física, sino por el desempleo y las políticas asistenciales estatales. El trabajo infantil no ha sido erradicado y la actividad continúa desgastando la salud de los trabajadores.

En resumidas cuentas, y sin perjuicio de sus dosis diferenciales de violencia, el régimen laboral de los mensúes y el modelo de explotación del tarefero contemporáneo guardan indudables paralelismos y semejanzas entre sí, y nada tienen que envidiar a las condiciones reinantes en los talleres de trabajo esclavo y las redes de sub-contratación de África, Asia y el resto de América Latina. Y al igual que ayer, el telón de fondo es exactamente el mismo: las obscenas ganancias acumuladas por grandes productores agrícolas y molinos yerbateros y la reproducción del poder social y dinerario de las oligarquías y élites políticas de la región.

\section{REFERENCIAS}

Aiani, B. (2017). Tareferos y trabajo precario: un estudio comparativo. En J. Gortari, M. L. Roa \& D. Re. (comps.), Tareferos. Vida y trabajo en los yerbales (pp. 217-230). Posadas, Argentina: EDUNAM.

Alcaráz, A. D. (2014). La conformación de una élite regional en el extremo norte del Altoparaná: la poderosa compañía Matte Larangeira. La Rivada, 2(3). Recuperado de http://argos.fhycs.unam.edu.ar/bitstream/handle/123456789/548/Alacaraz\%20 Alberto\%20dossier\%20La\%20Rivada\%203.pdf?sequence=1 \&isAllowed $=y$

Alcaráz, A. D. (2019). El liderazgo carismático empresarial enfrentado al poder burocrático del Estado: el conflicto por los yerbales entre la empresa Domingo Barthe y el gobernador Juan José Lanusse (1896-1905). Antíteses, 12(23), 466-486. https://doi. org/10.5433/1984-3356.2019v12n23p466

Alvira, P. (2009). Infierno verde. «Las aguas bajan turbias» y la explotación de los mensúes en el Alto Paraná (1880-1940). Naveg@mérica. Revista electrónica de la Asociación Española de Americanistas, 3. Recuperado de http://revistas.um.es/navegamerica

Báez, A. \& Gortari, J. (2018). El agro misionero y la represión durante la última dictadura civico-militar: testimonios. Posadas: EDIUNAM.

Bagú, S. (1969). Economía de la sociedad colonial. Buenos Aires: Centro Editor de América Latina.

Barret, R. (1908). Lo que son los yerbales. Buenos Aires: Proyección.

Corbey, N. S., Koffman, L., Orso, E., Ribone, E., Rodríguez Guerrero, P. \& Uría, M. C. (2013). Formación de precios oligopólica: el caso del sector yerbatero. Rosario: Red de Economía Política de Rosario.

DINREP. (2014). Necesidades Básicas Insatisfechas (NBI), Información censal del año 2010 (versión ampliada con datos departamentales). Buenos Aires: Dirección Nacional de Relaciones con las Provincias. 
El Territorio. (2015, 21 de mayo). Duras acusaciones a Puerta en el pedido de indagatoria. Recuperado el 10 de diciembre de 2019, de https://www.elterritorio.com.ar/durasacusaciones-a-puerta-en-el-pedido-de-indagatoria-4205087507055318-et

Flood, C. (1972). Estudio de la mano de obra transitoria en la Provincia de Misiones. Buenos Aires: Dirección Nacional de Economía y Sociología Rural.

Forni, P. (2016). La recuperación de una tecnología tradicional: ¿̇una alternativa para la agricultura familiar? La asociación de productores de yerba mate en sistema barbacuá del centro de la provincia de Misiones, Argentina. Redes, 21(3), 48-65. https://doi. org/10.17058/redes.v21i3.7043

Gallero, M. C. (2019). Cambios y permanencias en la producción de yerba mate. Un estudio desde la historia ambiental en Misiones (Argentina). HALAC Historia Ambiental, Latinoamericana y Caribeña, 9(1), 223-257. https://doi. org/10.32991/2237-2717.2019v9i1.p223-257

Garavaglia, J. C. (1983). Mercado interno y economía colonial: tres siglos de historia de la yerba mate. México: Enlace Grijalbo.

Gómez Lende, S. (2015). Acumulación por desposesión y conflictos espaciales. La minería metalifera en la Argentina contemporánea. Saarbrücken: Editorial Académica Española.

Gortari, J. (2012). Mate en jaque. Maiz, 1, 72-76.

Gortari, J. (2013). Yerba mate: claroscuros de un negocio próspero. Realidad Económica, $280,27-43$.

Gortari, J. (2017a). Los mensúes del siglo XXI. En J. Gortari, M. L. Roa, \& D. Re (comps.), Tareferos. Vida y trabajo en los yerbales (pp. 91-119). Posadas, Argentina: EDUNAM.

Gortari, J. (2017b). Acumulación originaria: trabajo esclavo y connivencia de gobierno. En J. Gortari, M. L. Roa, \& D. Re (comps.), Tareferos. Vida y trabajo en los yerbales (pp. 59-90). Posadas, Argentina: EDUNAM.

Gortari, J. (2017c). «Maldita» yerba mate: explotación de la mano de obra en las minas yerbateras del Paraguay colonial. TSN. Trasatlantic Studies Network: Revista de Estudios Internacionales, 2(3), 39-53.

Gortari, J. (2018). Situación económica y social del sector yerbatero. Recuperado el 10 de diciembre de 2019, de http://www.iade.org.ar/noticias/situacion-economica-y-socialdel-sector-yerbatero

Gortari, J., Roa, M. L. \& Re, D. (comps.). (2017). Tareferos. Vida y trabajo en los yerbales. Posadas: EDUNAM.

Harvey, D. (2004). El nuevo imperialismo. Madrid: Akal.

Harvey, D. (2007). Breve historia del neoliberalismo. Madrid: Akal.

Harvey, D. (2014). Diecisiete contradicciones y el fin del capitalismo. Quito: IAEN.

Haugg, D. E. (2016). Cuerpo del trabajo: «Yo me crié en la tarefa, no sé hacer otra cosa de trabajo, cuando me di cuenta, ya era tarefera». Misiones, Argentina. ETNICEX, 8, 51-60. 
Ibarguren, M. (2017). Contratismo rural en la actividad yerbatera: ¿hombres de paja o empresas de servicios? En J. Gortari, M. L. Roa, \& D. Re. (Comp.), Tareferos. Vida y trabajo en los yerbales (pp. 303-328). Posadas, Argentina: EDUNAM.

INDEC. (1990). Censo Nacional Agropecuario 1988. Resultados definitivos. Total del país y provincias. Buenos Aires: Instituto Nacional de Estadística y Censos.

INDEC. (2005). Censo Nacional Agropecuario 1988. Resultados definitivos. Total del país y provincias. Buenos Aires: Instituto Nacional de Estadística y Censos.

Marini, R. (1991). Dialéctica de la dependencia. México: Ediciones Era.

Marx, K. (1968). El capital. Crítica de la economía politica. Tomo I. México, D. F.: Fondo de Cultura Económica.

MECON. (2015a). Misiones: fichas provinciales. Buenos Aires: Ministerio de Economía de la Nación.

MECON. (2015b). Corrientes: fichas provinciales. Buenos Aires: Ministerio de Economía de la Nación.

Misiones on Line. (2013, 17 de junio). Detectaron trabajo esclavo en establecimientos agropecuarios de Misiones. Recuperado el 10 de diciembre de 2019, de https:// misionesonline.net/2013/06/17/detectaron-trabajo-esclavo-en-establecimientosagropecuarios-de-misiones/

Misiones on Line. (2014, 3 de febrero). Denuncian trabajo esclavo en conocidas empresas misioneras. Recuperado el 10 de diciembre de 2019, de https://misionesonline. net/2014/02/03/denuncian-trabajo-esclavo-en-conocidas-empresas-misioneras/

Misiones on Line. (2015, 5 de mayo). RENATEA denuncia nuevos casos de presunta trata laboral en el sector yerbatero. Recuperado el 10 de diciembre de 2019, de https:// misionesonline.net/2015/05/05/renatea-denuncia-nuevos-casos-de-presunta-tratalaboral-en-el-sector-yerbatero/

Niklison, E. (1914). Boletín del Departamento Nacional del Trabajo n. 26. Buenos Aires: Editorial Alsina.

Oscherow, H. (2017). Tareferos: condiciones de vida y vulnerabilidad social. En J. Gortari, M. L. Roa, \& D. Re. (Comp.), Tareferos. Vida y trabajo en los yerbales (pp. 189-215). Posadas, Argentina: EDUNAM.

Palmbaum, V. (2017). Yerba mate: tareferos sin minimas condiciones de subsistencia. Recuperado el 10 de diciembre de 2019, de https://www.marcha.org.ar/yerba-mate-tareferossin-minimas-condiciones-de-subsistencia/

Pereyra, S. P. (2013). La cosecha de yerba mate realizada por asalariados urbanos. En VII Jornadas de Jóvenes Investigadores. Jornadas llevadas a cabo en el Instituto de Investigaciones Gino Germani, Buenos Aires, Argentina.

Rau, V. (2012). Cosechando yerba mate. Estructuras sociales del mercado de trabajo agrario en el nordeste argentino. Buenos Aires: Ciccus. 
Re, D. A. (2015). La «ayuda» infantil en la tarefa de yerba mate. Cultura, mercado y legislación. Revista Conflicto Social, 14(8), 221-242.

Rivas Zelaya, A. (2011, 27 de enero). Argentina: yerba mate y esclavitud. Recuperado el 10 de diciembre de 2019, de http://csa-csi.org/NormalNews.asp?pageid=10226

Roa, M. L. (2013). Tarefa que me hiciste sufrir... La emocionalidad en la constitución del self de los jóvenes de familias tareferas. Trabajo y Sociedad, 20, 323-343.

Rodríguez, L. (2015). Estado y producción: la actividad yerbatera en el Territorio Nacional de Misiones (1926-1953). Folia Histórica del Nordeste, 23, 43-64. https://doi. org/10.30972/fhn.02334

Slutzky, D. (2011). Estructura social agraria y agroindustrial del nordeste de la Argentina: desde la incorporación a la economía nacional al actual subdesarrollo concentrador y excluyente. Buenos Aires: IADE.

Traglia, C. (2014). Nuevas conceptualizaciones del trabajo: proceso de articulación entre las políticas sociales y las políticas laborales en el mercado yerbatero de Misiones, Argentina. La Rivada, 2(3). Recuperado de http://larivada.com.ar/index.php/ ediciones-anteriores/48-numero-3-diciembre-2014

Walsh, R. (1966). Argentina ya no toma mate. Revista Panorama, 43, 1-10. 